\title{
IMPROVING STUDENTS' READING NARRATIVE TEXT COMPREHENSION THROUGH STORY MAPPING TECHNIQUE AT GRADE VIII MTSN 2 PADANGSIDIMPUAN
}

\author{
By: Eka Sustri Harida ${ }^{1}$
}

\begin{abstract}
ABSTRAK
Penelitian ini bertujuan untuk meningkatkan pemahaman bacaan siswa dengan menggunakan teknik Story Mapping di kelas VIII MTs Negeri 2 Padangsidimpuan. Sebagian besar siswa berprestasi rendah dalam membaca pemahaman teks naratif, siswa pasif di kelas, siswa kurang tertarik membaca dan juga kurang motivasi, dan siswa tidak memiliki teknik pembacaan yang sesuai. Masalahnya dipengaruhi oleh faktor internal dan eksternal. Masalah dalam faktor internal adalah kesulitan siswa dalam mengidentifikasi karakter, mengidentifikasi setting, mengidentifikasi masalah, mengidentifikasi koda, dan mengidentifikasi kosakata dalam konteks. Masalah dalam faktor eksternal adalah motivasi, gangguan, meminta izin, dan tidur di kelas. Penelitian ini bertujuan untuk mendeskripsikan prestasi belajar siswa dalam membaca pemahaman dan untuk mengetahui faktor - faktor yang mempengaruhi pemahaman bacaan siswa dengan menggunakan Teknik Story Mapping di kelas VIII MTs Negeri 2 Padangsidimpuan. Metode yang digunakan dalam penelitian ini adalah penelitian tindakan kelas, dengan menerapkan desain Hopkins yang terdiri dari identifikasi masalah dan melakukan empat tahap. Selain itu, untuk memecahkan masalah membaca, peneliti menerapkan Teknik Story Mapping. Dalam penelitian ini, peneliti menggunakan dua tes baca dan dua siklus. Partisipan adalah kelas VIII-5 yang terdiri dari 30 siswa dan juga ada kolaborasi dengan guru bahasa Inggris. Berdasarkan hasil penelitian, menunjukkan nilai mean perbaikan siswa. Uji pertama pada siklus I adalah $70,33(43,33 \%)$ dan uji kedua pada siklus II adalah 80,83 (86,66\%). Dapat disimpulkan bahwa nilai rata-rata pada siklus kedua lebih tinggi daripada siklus pertama. Kemudian hasil perhitungannya menjadi $=5,58$, ttabel dengan $\mathrm{df}=29$, tingkat signifikasi pada $(\mathrm{tt} 5 \%=2,045)$. Dapat diketahui bahwa hasilnya lebih besar dari tt. Berdasarkan catatan observasi menyatakan bahwa siswa mendapat peningkatan dan siswa lebih aktif dan tertarik untuk belajar membaca pemahaman. Berkaitan dengan hasil wawancara, dapat diketahui bahwa pemahaman bacaan siswa telah membaik. Ini menegaskan bahwa dengan menggunakan Teknik Story Mapping meningkatkan pemahaman teks naratif membaca naratif.
\end{abstract}

Keyword: Reading Narrative and Story Mapping

\footnotetext{
${ }^{1}$ Writer is an English Education Departement Lecturer of Tarbiyah and Teacher Training Faculty (FTIK), Institute for Islamic Studies (IAIN) Padangsidimpuan.
} 


\section{A. INTRODUCTION}

Reading is the basic foundation of all aspects in learning. Other skills in English such as (speaking, writing, and listening) come from what have been read. First, reading can enrich the vocabularies. Readers use reading skill to interpret and understand written words on a page. Readers often read from variety of materials in which they want to find out more about the world where they live and use the information to improve their life. In contrast, even though reading skill is very important, but in fact it still had some problems at grade VIII in MTsN 2 Padangsidimpuan. Students did not know that reading very useful. Students actually made noisy when they were studying. Although, Reading is the basic foundation of all aspect in learning, students were lazy for reading in the class. Then, it has been known that reading can develop the mind, but students did not have high motivation in reading because they thought that reading is an action to read only without getting product that could be taken after reading.

First, students' reading achievement was low. It was proved by students' skill in reading. Then, it had been found that the average of students' reading comprehension achievement of grade VIII in MTsN 2 Padangsidimpuan about 60 score. Moreover, the standard of value in this school was 75. It means that students' reading achievement was still unsatisfactory and it had not achieved the target needed.

Second, students always felt boring or lazy when they were studying. It could be seen that students did not read the text when teacher was giving the text. Students were silent only and almost be sleeping in the class. Sindy Melani as student at grade VIII said that reading is boring because they did not know the meaning and cannot comprehend the text. ${ }^{2}$

Third, Mrs. Murti Sastrawati, S.Pd said that she uses Grammar Translate Method (GTM) for teaching reading. She asked students for searching the text in English and translate into Indonesian. It made students have lack of reading interest and reading motivation. Students do not have the good strategy for reading the text. Because of reading strategy is not suitable in reading, students were passive in the class.

${ }^{2}$ Sindy Melani as a student in the $8^{\text {th }}$ class, Private Interview, (MTsN 2 Padangsidimpuan: October $3^{\text {rd }}, 2016$ at 09.00 a.m). 
Based on the problems above, there are three techniques that can be used to solve the problem. These techniques are related with the problem that occurs in the class. First, Pre-Questioning is the strategy before reading, students give some questions that related with the text. It will help students for guessing the text. In other hand, Pre-Questioning has disadvantage, as follow: the students did not know what they will ask to the text. Second, Jigsaw is one technique to improve reading narrative text comprehension. Based on discussion above, researcher is interested in conducting a classroom action research (CAR) by title: "Improving Students' Reading Narrative Text Comprehension through Story Mapping Technique at Grade VIII MTsN 2 Padangsidimpuan”.

\section{B. Formulation of the Problem}

There are two formulations of problem in this research, they are:

1. To what extent does Story Mapping Technique improve students' reading narrative text comprehension at grade VIII MTsN 2 Padangsidimpuan?

2. What factors influence improving students' reading narrative text comprehension at grade VIII MTsN 2 Padangsidimpuan?

\section{Theoretical Description}

\section{The Nature of Reading Narrative Text Comprehension}

Reading is an interaction between the reader and the author where the prior knowledge such as knowledge of content, structure, and vocabulary. It enables the reader to make meaning from the text Reading is a set of skills that involves making sense and deriving meaning from the printed word. In order to read, we must be able to decode (sound out) the printed words and also comprehend what we read. ${ }^{3}$ In other word, reading is a complex process in which the recognition and comprehension of written symbols are impacted by the perceptual skills, the word an analysis skills, the experience, language background, the mind set and the reasoning ability of the reader. ${ }^{4}$ Reading is an

\footnotetext{
${ }^{3}$ Caroline T. Linse, series editor: David Nunan, Practical English Language Teaching: Young Learners, (New York: Mc Graw Hill Company, inc, 2005), p. 69.

${ }^{4}$ Albert J. Harris, How to Increase Reading Ability, (New York: David Mckay Company, 1969), p. 3.
} 
interaction between reader and writer. It means that transferring symbol on the text from writer brain to reader brain.

Comprehension is the power to understand language (written and spoken). ${ }^{5}$ It means that comprehension will construct the language to take the meaning by connecting the information with the readers' background knowledge. So, comprehension is the ability to construct the meaning in the written language as a media to find the information in order can answer the question.

Based on the third explanation above, it can be concluded that reading comprehension is the most important in the final. It can be seen from the exercises which related with what reader has read. Reading without comprehension is useless. However, we read but do not know what else in the text. It means that we do not take comprehension.

\section{The General of Narrative Text}

Narrative is a text focusing specific participants. Its social function is to tell stories or past events and entertain the readers. Narrative deals with problematic events which lead to a crisis or turning point of some kind, which in turn finds a resolution. A narrative is a text that tells a story and, in doing so, entertains the audience. Also, its narrative purpose is mainly to inform often contains large passage arranging the events in a story strictly in chronological order. According to Sanggam Siahaan and Kisno Shinoda, narration is any written English text in which the writer wants to amuse, entertain people, and to deal with actual or vicarious experience in different way. ${ }^{6}$ Narrative can be imaginary or factual (fairy tales, mysteries, fables, romances and adventure stories, myths and legends).

Anderson and Kathy describe many different types of narrative; namely humor, romance, crime, real life fiction, historical fiction, mystery, fantasy,

\footnotetext{
${ }^{5}$ A. S. Hornby, Op. Cit., p. 173.

${ }^{6}$ Sanggam Siahaan and Kisno Shinoda, General Text Structure, (Yogyakarta: Graha Ilmu, 2008),
} p. 73. 
science fiction, diary novel, and adventure. ${ }^{7}$ Narrative text includes the narration text that talking about experiences. According to John Langan, in narration, writer tells the story of something that happened. ${ }^{8}$ It means that narration is done by somebody in the past time.

The main characteristic of narrative text includes a problem and coda. The problem will be solved in the last story. The content of narrative text is consist of imagination or the factual idea but entered an imagination or engineering. ${ }^{9}$ Narrative text usually gives the learning to the reader. Based on the explanation above, researcher concludes that narrative text is the text tells about the last time. It tells about the real action or the unreal action. Next, some story on the novel, tales, fable, legend and so on used narrative text.

\section{a. The Kinds of Narrative Text} includes: ${ }^{10}$

According to Mark and Anderson, narrative text has some kinds. It

1) Humor, the aims to make the audience laugh as part of retelling story.

2) Romance, typically tells of two lovers who overcome difficulty to end up together.

3) Science function, use a setting involving science and technology.

4) Diary - novels, the text presented like diary entries adventure, typically tells of exciting dangerous journey of experience.

\section{b. The Purpose of Narrative Text}

The basic purpose of narrative is to entertain, to gain and hold a readers' interest. Furthermore, narratives can also be written to teach or inform, to change attitudes/social opinions. Narratives sequence people/characters in time and place but differ from recounts in that through the sequencing. The stories set up one or more problems, which must

\footnotetext{
${ }^{7}$ Mark Anderson and Kathy Anderson, Text Types in English 2, (South Yarra: Mcmillan, 2003), p. 18

${ }^{8}$ John Langan, Collage Writing Skills with Readings, (New York: McGraw-Hill Book Company), p. 111.

${ }^{9}$ Otong Setiawan Djuharie, Tekhnik dan Panduan Menulis Melalui Eksplorasi Model dan Latihan Book 3 Essay Writing, (Bandung: Yrama Widya, 2009), p. 168.

${ }^{10}$ Mark Anderson and Kathy Anderson, Op. cit., p. 28.
} 
eventually find a way to be resolved. ${ }^{11}$ So, it means that narrative text has the social function to entertain the reader and also gives the learning.

Text function of narrative text is to amuse, entertain and to deal with actual or vicarious experience in different ways. Narration deals with problematic events which lead to a crisis or turning point of some kind, which in turn finds a resolution. ${ }^{12}$ Reader can take the social function on the narrative text such as attitude and opinion. It usually entertains the reader. Some narrative texts will create the way to solve the problem.

\section{c. Generic Structure of Narrative Text}

According to Mark and Kathy Anderson, narrative text provides the elements of narrative text; they are consists of orientation, complication, sequence event, resolution and coda. ${ }^{13}$ To make it clear, we will explain as below:

1) Orientation: This is the part in which the narrator tells the audience about who is in the story, when the story is talking place and where the action is happening. So, it can be called as introduction the part of the story. The reader can figure out what will happen next and who are included.

2) Complication: The part of the story where the narrator tells about something that will begin a chain of the event. These events will affect one or more of character. So, this part is talking about the totally playing of character.

3) Sequence event: Narrator tells some events in the story.

4) Resolution: This part can be found in the last story. Here, the complication will be solved.

5) Coda Provides a comment or moral based on what has been learned from the story.

\footnotetext{
${ }^{11}$ Rachmat Wahidi, Genre of the Text, accessed from http://rachmatwahidi.wordpress.com, at October $12^{\text {th }}, 2014$ retrieved on 04.00 am, p. 7.

${ }^{12}$ Sanggam Siahaan and Kisno Shinoda, Op. cit., p. 73.

${ }^{13}$ Ibid., p. 12.
} 
Hoey gives us the following label which could be easily understood and used by children: situation, problem, and evaluation. ${ }^{14}$ It means that in narrative text consist of situation (place, time, season, and participant), problem (the important clue), and evaluation (the coda or moral).

\section{d. Language Future in Narrative Text}

There are some language futures in Narrative text. It contained in narrative text. ${ }^{15}$ They can be used as the characteristics to identify narrative in the text. It can be below:

1) Past tense (killed, drunk, etc).

2) Adverb of time (Once upun a time, one day, etc).

3) Time conjunction (when, then, suddenly, etc).

4) Specific character. The character of the story is specific, not general. (Cinderella, Snow White, Alibaba, etc).

5) Action verbs. A verb that shows an action. (killed, dug, walked, etc).

6) Direct speech. It is to make the story lively. (Snow White said, "My name is Snow White"). The direct speech uses present tense.

Narrative text should have the characteristics above. it usually uses past tense in actions or the events. Then, it uses adverb of time in the story, time conjunction, specific character, and direct speech.

\section{The General Technique of Story Mapping}

\section{a. The Background Technique of Story Mapping}

In the century spanning the mid of 1880 s to the mid of 1980 , the language teaching profession was involved in a search. That search was for what has popularly been call "methods," or ideally, a single method, generalizable across widely varying audiences, that would successfully teach students a foreign language on the classroom. Historical accounts of the profession tend therefore to describe a succession of method.

\footnotetext{
${ }^{14}$ Judith Graham and Alison Kelly, Writing Under Control Third Edition, (London: Routledge, p. 106.

15 Adeulfayani, Narrative Text, accessed from https://adeulfayani.wordpress.com/narrative-text2/, at February $02^{\text {th }}, 2014$ retrieved on 11.30 am.
} 
Three decades age Edward Anthony (1963) gave us a definition that has quite admirably withstood of the test time. His concept of method was the second of three hierarchical elements, namely, approach, method, and technique. An approach, according to Anthony, is a set of assumptions dealing with the nature of language, learning, and teaching. Method is an overall plan for systematic presentation of language based upon a selected approach. Then, technique are the specific activities manifested in the classroom that are consistent with the method and therefore in harmony with an approach as well. ${ }^{16}$ In other word, technique includes all tasks and activities. They are almost always planned and deliberate. They are product of a choice made by teacher. You can think of a lesson as consisting of a numbers of techniques, some comprehension oriented, some clustering together to form task, some as a task in and of themselves. $^{17}$

Based on literature above, researcher concludes that technique is an activity that will be conducted with the related subject in the class. The technique can take out the product based on learning. Teacher gives the task, and students use the technique to solve or finish the task. Students need the coherent technique to give solving in order can finish the task.

\section{b. The definition and Concept of Story Mapping}

The term of story mapping consists of two different words. They are story and mapping. Based on Hornby in Oxford Advanced learner's Dictionary 'story' is a description of events and people that the writer or speaker has invented in order to entertain people. ${ }^{18}$ Story is also regarded as a fiction selection to entertain a reader; as a part of pleasure. On the other side, map is defined as a drawing to describe or give information about something, especially the way it is arranged or organized. So, if the word is added with -ing, become mapping, it could be defined as a sketch or drawing that shows location or relation between things or place. In other word it is an action to make a map.

\footnotetext{
${ }^{16}$ H. Dounglas Brown, Teaching by Principle: an Interactive approach to language pedagogy, (USA: Prentice Hall Regents, 1994), p. 48.

${ }^{17}$ Ibid., p. 137 .

${ }^{18}$ A. S. Hornby, Op.cit., p. 815.
} 
Story maps outline the structure of a story with specific headings (such as setting, main character, events). Students filled the story mapping with single word or phrase each heading. Story maps are particularly appropriate for students, who may not be familiar with the discourse structure of a text. ${ }^{19}$ So, story mapping is related to set, main character, setting, events, problem, and coda.

It means that based on the concept of the story mapping, students are free to create the graphic that involve the story. Every student has the different story mapping based on the imaginary. So, it can improve students' reading in narrative text.

c. The Application of Story Mapping in Teaching Narrative Text

\section{Comprehension}

From the procedure of the Story Mapping Technique above, it can be concluded that story mapping can be applied such as below:

\section{Table 1}

\section{The Steps of Applying Story Mapping Technique}

\begin{tabular}{|c|c|c|}
\hline Step & Teacher Activity & Students Activity \\
\hline Step 1 & $\begin{array}{l}\text { Introduce students about the concept of } \\
\text { story mapping }\end{array}$ & Listening teacher's explanation \\
\hline Step 2 & $\begin{array}{l}\text { 1) Explain the major components of story } \\
\text { mapping through identifying a story } \\
\text { first concerning to figure out the title, } \\
\text { the important characters and } \\
\text { personality traits of specific } \\
\text { participants of a story. }\end{array}$ & $\begin{array}{l}\text { 1) Read the title of story } \\
\text { 2) Build question about main } \\
\text { character, setting, problem, } \\
\text { coda. }\end{array}$ \\
\hline Step 3 & $\begin{array}{l}\text { 1) Ask students for independently } \\
\text { reading. } \\
\text { 2) Ask students to create a visual } \\
\text { representation of the text. }\end{array}$ & $\begin{array}{l}\text { 1) Students read the text by } \\
\text { taking note. } \\
\text { 2) Create Story Mapping after } \\
\text { reading as individual. } \\
\text { 3) Compare story mapping each } \\
\text { other }\end{array}$ \\
\hline Step 4 & Give the exercise as evaluating. & $\begin{array}{l}\text { Answer the question based on the } \\
\text { story. }\end{array}$ \\
\hline
\end{tabular}

${ }^{19}$ J. Michael O, Malley and Lorraine Valdez Pierce, Authentic Assessment For English Language Learners, (USA: Addison-Wesley Publishing Company, Inc, 1996), p. 102-106. 
Based on the step of applying Story Mapping above, there are some steps to teach Narrative text in reading comprehension in the classroom. It starts from the opening, main activity, and closing. It will be explained in the table 1.3 below:

Table 2

Teaching Reading Narrative Text through Story Mapping

\begin{tabular}{|c|c|c|}
\hline No. & Stage & Activity \\
\hline 1. & Opening & $\begin{array}{l}\text { - Teacher introduces the learning purpose } \\
\text { - Teacher gives motivation based that related with the } \\
\text { learning. } \\
\text { - Opening students' background knowledge. } \\
\text { - Review the last material that conducting to the next } \\
\text { material. }\end{array}$ \\
\hline 2. & Main Activity & $\begin{array}{l}\text { - Presenting Material } \\
\checkmark \text { Before enter to the material, as well as possible } \\
\text { introduce about the description of learning. } \\
\text { - Modeling of Story Mapping Technique } \\
\checkmark \text { Teacher performs Story Mapping technique based on } \\
\text { the narrative text. } \\
\text { - Feedback } \\
\checkmark \text { Teacher gives some question based on the narrative } \\
\text { text. } \\
\text { - Giving independently task } \\
\checkmark \text { Teacher asks students to create story mapping based on } \\
\text { the text. }\end{array}$ \\
\hline 3. & Closing & $\begin{array}{l}\text { - Evaluation } \\
\checkmark \text { Teacher evaluates students' result about story mapping. } \\
\checkmark \text { Teacher asks students for giving conclusion based on } \\
\text { their story mapping. } \\
\text { - Notes } \\
\checkmark \text { Teacher must take students' motivation } \\
\checkmark \text { Teacher must teach as interesting as possible. } \\
\checkmark \text { Time allocation is so important. } \\
\checkmark \text { Teacher must be clearly in speaking. }\end{array}$ \\
\hline
\end{tabular}

\section{Research Methodology}

\section{Location and Schedule of the Research}


Researcher did the research in MTsN 2 Padangsidimpuan. It is located in Jalan T. Rizal Nurdin Km, 4.5 Palopat. This research was done in VIII-5. Researcher did research starting from November 2016 up to finish.

\section{Research Design}

Research is an attractive way to build evidence based on explanation for events and phenomena. The research conducted with class action research. Researcher did action research to improve students reading narrative text comprehension through story mapping. Design is a plan and a process. It is personalized road map that we create to address the questions and curiosities we have about our teaching. ${ }^{20}$ Action research involved designing our teaching with our students. We took an active part in designing our teaching and our relationship with students to plan and develop a material. Action is an activity that changes a human situation by initiating something new.

Action research is the research would be done because of problem. The problem would be solved by doing an action. According to John Elliot, action research starts with a feeling- a sense of frustration, or better yet of creative possibilities for action, and the pronounced commitment to "do it differently", to bring one's practice in line with one's values and aspiration.

\section{Participant}

The participants are 30 students. It conducted at grade VIII on the VIII-5 in the second semester 2016-2017 academic years MTsN 2 Padangsidimpuan. Research would be done collaborating with the teacher, at grade VIII MTsN 2 Padangsidimpuan.

\section{Instruments of Collecting Data}

Instruments of collecting data are the tools that used to collect research data. Class action research used the instruments such as observation, interview, and test.

1) Observation

\footnotetext{
${ }^{20}$ Mary Louise Holly at al., Action Research for Teacher Second Edition, (Merrill Prentice Hall:Columbus Ohio, 2005), p. 129.
} 
Observation is the technique to collect data by observing every moment and write down it. Researcher monitored how the teacher was teaching and how the students responded the teacher.

2) Interview

Conducting interviews could be a powerful technique for an action researcher. Interviewing consisted of asking questions of an individual or a group of individuals and obtaining their verbal responses. The respondents generally give their candid opinions, which are then directly recorded or paraphrased by the interviewer. ${ }^{21}$ Interview is one of the instruments for collecting the data used orally between researcher and students. Interview would support the data from observation. And then, increased the data because every students have the different responses.

3) Test

Test is one of instruments in collecting data for determining the students' aspect of cognitive. According to Agar, he suggests that information from interviews can serve as the methodological core against which data can be used to feed ongoing interview ${ }^{22}$. Furthermore, a test is a method of measuring a person's ability knowledge, or performance in a given domain ${ }^{23}$. So, test measured students' ability especially in reading.

\section{E. Findings/ Data Presentation}

Related to Maestas and Croll, they said that using a reader-directed story mapping would guide procedure structured to take readers' attention to the elements of story grammar (e.g., character, setting, problem, and coda) during reading. It could help students more comprehend the text. then, it would interest students for reading.

There are three thesis that researcher used as related finding. Then, researcher will explain it. It caused the one of purpose of this research is to describe students' achievement in reading narrative text through story mapping technique at grade

\footnotetext{
${ }^{21}$ Daniel R. Tonal, Action Research for Educator second edition, (New York: Rowman \& Littlefield Publishers, 2010), p. 44.

${ }^{22}$ Geoffirey E. Mills, Action Research A Guide For The Teacher Researcher Second Edition, (Ohio: Merrill Perintice Hall, 2003), p. 58.

${ }^{23} \mathrm{H}$. dounglas Brown, Language Assesment Principles and Classroom Practice, (San Francisco: Longman, 2004), p. 3.
} 
VIII MTsN 2 Padangsidimpuan. Story mapping could improve students' reading narrative text comprehension.

First, Denny Pratama, had done research in Tanjung pura University writes the title: “Improving Students' Reading Comprehension Through Group Work Technique". The research had done at grade 8 SMPN 14 Pontianak. He has done three cycles in the class VIII-C. In the first cycle, he found the score of students in reading narrative text was 60.07 . In the second cycle, found the score of students in reading narrative text was 63.33 score. In the third cycle, found the score of students in reading narrative text was 68.1 score. The result was satisfying, 68.1 it showed the students could achieve the standard minimum score in this school. The researcher and the collaborator concluded that the problems were solved well.

Second, Ni Kadek Listiani had done the research "Improving Reading Comprehension Through Think Pair Share At The Eighth Grade Students Of SMPN 2 Abiansemal In Academic Year 2013 / 2014". She did the research by doing an action like Think Pair Share. As a conclusion, in the cycle 1 found 61.20 by using the technique. She did again the cycle 2 and improved pre-test and cycle 1 , the mean is 81.73 . It means that reading narrative text was improved.

Third, Muhammad Romli, he had done research by Class Action Research (CAR). The title is 'Improving TheStudents' Reading Comprehension Of' Narrative Text Through Story Mapping". . He gave pre-action to know student's ability the result of pre action test which class average score was only 65.14. Based on the research, students' comprehension on narrative text is improving. It is seen from the cycle 1 and cycle 2 . Based on the data that class average score was 75.43, which score was higher than before. Then, in the cycle 2 it had had 82.57 score.

\section{E. The Conclusion}

Based on the result of the classroom action research, it could be concluded that story mapping technique improved students' reading narrative text comprehension at grade VIII MTs Negeri 2 Padangsidimpuan. It based on the students' reading comprehension, the mean score in which was in first cycle was $70.33(43.33 \%)$ and in second cycle was $80.83(86.66 \%)$. There were four of external factors that influencing students' reading comprehension in first cycle and second cycle, like motivation, disturbance, asking permission to the bathroom, and 
sleeping in the classroom. Therefore, the hypothesis in the research could be accepted. The learning, the value and the condition in reading comprehension by using story mapping technique has shown the good improvement in class VIII-5 MTs Negeri 2 Padangsidimpuan.

\section{REFERENCES}

Agus Suprijonno, Cooperative Learning teori \& Aplikasi PAIKEM, Yogyakarta: Pustaka Pelajar.

Anderson, Mark and Kathy Anderson, Text Types in English 2, South Yarra: Mcmillan, 2003.

Broughton, Geoffrey, Teaching English as a Foreign Language (Second Edition), USA: Routledge, 1980.

Brown, H. Dounglas, Language Assesment Principles and Classroom Practice, San Francisco: Longman, 2004.

Brown, H. Dounglas, Teaching by Principle: an Interactive approach to language pedagogy, USA: Prentice Hall Regents, 1994.

Brunner, Judy Tilton, I Don't Get It! Helping Student Understand What They Read, UK: Rowman \& Littlefield Publishers, Inc, 2011.

Daniels, Harvey and Marilyan Bizar, Teaching the Best Practice, Portland: Standhouse Publisher, 2015.

Gay and Peter Airasian, Education Research Competencies for Analysis and Application, USA: Prentice Hall, 2000.

Graham, Judith and Alison Kelly, Writing Under Control Third Edition, London: Routledge,

Harmer, Jeremy, The Practice of English Language Teaching (Third Edition Completely Revises and Update), England: Longman, 2003.

Harris, Albert J., How to Increase Reading Ability, New York: David Mckay Company, 1969.

Hartono, Statistik: Untuk Penelitian, Yogyakarta: Pustaka Pelajar Offset, 2004.

Holly, Mary Louise, at al., Action Research for Teacher Second Edition, Merrill Prentice Hall:Columbus Ohio, 2005.

Klingner, Janette K. et. al., Teaching Reading Comprehension to Students with Learning Difficulties, US: The Guilford Press, 2007.

Langan, John, Collage Writing Skills with Readings, New York: McGraw-Hill Book Company, 
Linse, Caroline T. series editor: David Nunan, Practical English Language Teaching: Young Learners, New York: Mc Graw Hill Company, inc, 2005.

Michael O, J., Malley and Lorraine Valdez Pierce, Authentic Assessment For English Language Learners, USA: Addison-Wesley Publishing Company, Inc, 1996.

Mills, Geoffirey E, Action Research A Guide For The Teacher Researcher Second Edition, Ohio:

Nunan, David, Practical English Language Teaching, New York: MC.Grow Hill, 2003.

Otong Setiawan Djuharie, Tekhnik dan Panduan Menulis Melalui Eksplorasi Model dan Latihan Book 3 Essay Writing, Bandung: Yrama Widya, 2009.

Rangkuti, Ahmad Nizar, Metode Penelitian Pendidikan: Pendekatan Kuantitatif, Kualitatif, PTK, dan Penelitian Pengembangan, Bandung: Citapustaka Media, 2014.

Ridwan, Belajar MudahPenelitian Untuk Guru-Karyawan dan Penelitian Pemula, Bandung: Penerbit Alfabeta, 2012.

Siahaan, Sanggam and Kisno Shinoda, General Text Structure, Yogyakarta: Graha Ilmu, 2008.

Tankersley, Karen, The Threads of Reading; Strategies for Literacy Development, USA: ASCD, 2003.

Tarigan, Henry Guntur, Membaca Sebagai Sebuah Keterampilan Berbahasa, Bandung: Agkasa, 2005.

Tonal, Daniel R., Action Research for Educator second edition, New York: Rowman \& Littlefield Publishers, 2010. Wayne Otto, et. al., How to Teaching Reading, Philippines: Addison-Wesley Publishing Company, 1979.

Weir, Cryril J. Communicative Language Testing, UK: Printice Hall, 1990.

Wina Sanjaya, Penelitian Tindakan Kelas, Jakarta: Prenada Media Group, 2011.

Zainal Aqib, et. al., PTK untuk Guru SMP, SMA, SMK, Bandung: CV. Yrama Widya, 2008. 